\title{
PENGELOLAAN KEUANGAN BERBASIS KOMPUTER BAGI UPK KECAMATAN KISARAN BARAT DAN KECAMATAN KISARAN TIMUR KABUPATEN ASAHAN
}

\author{
Elly Rahayu* ${ }^{1}$ Wan Mariatul Kifti ${ }^{2}$ Rohminatin $^{3}$ \\ 1,2,3 Sistem Informasi STMIK Royal Kisaran
}

\begin{abstract}
The Financial Management Unit (UPK) is one of the managing units of financial activities. One of its tasks is to bring together people who have the same needs or types of businesses to form business groups. The UPK is also tasked with channeling and developing government aid funds for the development of micro enterprises in each kelurahan. Government through the Ministry of Public Works and Public Housing continue to develop the capacity of the community through various types of training that are scheduled each year. One of training forms conducted is financial management training for the Financial Management Unit located in 25 urban subdistricts of East Kisaran and West Kisaran District. This financial management training is considered very important because UPK capacity building is needed in performing its duties as a financial management unit. The purpose of this Community Service activity is to improve the knowledge of UPK on Financial Management so that it can be applied to the community, to be able to do the recording of income and expenditure with good and detailed, to give reference to UPK in order to be able to educate financial management to community and introduce MYOB application for UPK. The result of this activity is the implementation of Community Service activity which attended by UPK as many as 48 people.
\end{abstract}

Keywords: UPK, Financial, Management,MYOB

\begin{abstract}
Abstrak: Unit Pengelola Keuangan (UPK) merupakan salah satu unit pengelola kegiatan keuangan. Salah satu tugasnya adalah menghimpun masyarakat yang memiliki kebutuhan atau jenis usaha yang sama untuk membentuk kelompok-kelompok usaha. UPK ini juga bertugas menyalurkan serta mengembangkan dana bantuan pemerintah untuk pengembangan usaha mikro di masing-masing kelurahan.Pemerintah melalui Kementerian Pekerjaan Umum dan Perumahan Rakyat terus melakukan pengembangan kapasitas masyarakat melalui berbagai jenis pelatihan yang diagendakan setiap tahun. Salah satu bentuk pelatihan yang dilakukan adalah pelatihan pengelolaan keuangan bagi Unit Pengelola Keuangan yang berada di 25 kelurahan Kecamatan Kisaran Timur dan Kecamatan Kisaran Barat. Pelatihan pengelolaan keuangan ini dipandang sangat penting karena, pengembangan kapasitas UPK sangat dibutuhkan dalam menjalankan tugasnya sebagai unit pengelola keuangan. Tujuan dilakukannya kegiatan Pengabdian Masyarakat ini adalah untuk meningkatkan pengetahuan UPK terhadap Pengelolaan Keuangan sehingga dapat diterapkan ke masyarakat, untuk dapat melakukan pencatatat pemasukan dan pengeluaran dengan baik dan rinci, untuk memberikan acuan kepada UPK agar mampu melakukan edukasi pengelolaan keuangan kepada masyarakat dan mengenalkan aplikasi MYOB bagi UPK .Hasil kegiatan ini adalah terlaksananya kegiatan Pengabdian Masyarakat yang dihadiri UPK sebanyak 48 orang.
\end{abstract}

Kata kunci: UPK, Keuangan, Manajemen, $M Y O B$ 
Vol. 1, No. 2, Jul 2018, hlm. $63-68$

ISSN 2614-7912 (cetak)

ISSN 2622-3813 (online)

Available online at http://jurnal.stmikroyal.ac.id/index.php/jurdimas

\section{PENDAHULUAN}

Unit Pengelola Keuangan (UPK) yang pembentukannya difasilitasi oleh program Kotaku melalui Badan Keswadayaan Masyarakat (BKM) masing-masing kelurahan yang merupakan salah satu unit pengelola semua kegiatan keuangan. Salah satu tugasnya adalah menghimpun masyarakat yang memiliki kebutuhan atau jenis usaha yang sama untuk membentuk kelompokkelompok usaha. UPK ini juga bertugas menyalurkan serta mengembangkan dana bantuan pemerintah untuk pengembangan usaha mikro di masing-masing kelurahan. Pemerintah melalui Kementrian Pekerjaan Umum dan Perumahan Rakyat terus melakukan pengembangan kapasitas masyarakat melalui berbagai jenis pelatihan yang diagendakan setiap tahun. Salah satu bentuk pelatihan yang dilakukan adalah pelatihan pengelolaan keuangan bagi Unit Pengelola Keuangan Badan Keswadayaan Masyarakat (UPKBKM) yang berada di 25 kelurahan Kecamatan Kota Kisaran Timur dan Kecamatan Kota Kisaran Barat.

Pelatihan pengelolaan keuangan ini dipandang sangat penting karena, tugas UPK sebagai unit pengelola keuangan tentunya membutuhkan pengetahuan yang lebih baik sehingga UPK akan mampu memberikan masukan atau dorongan kepada kelompokkelompok swadaya masyarakat (KSM) ekonomi yang menjadi binaan dari UPK tersebut.

Pada tahun 2017, Pemerintah memberikan bantuan 1 unit komputer kepada setiap UPK agar UPK mampu melakukan tugasnya dengan baik dan akurat. Permasalahan yang muncul adalah pewngurus UPK yang terdiri dari seorang manajer, petugas pembukuan dan kasir tidak semuanya bisa menggunakan komputer. Oleh karenanya pelatihan ini dipandang perlu dilakukan tujuannya untuk memberikan untuk meningkatkan pengetahuan UPK terhadap Pengelolaan
Keuangan sehingga dapat diterapkan ke masyarakat, untuk dapat melakukan pencatatat pemasukan dan pengeluaran dengan baik dan rinci dengan menggunakan aplikasi pembukuan serta untuk memberikan acuan kepada UPK agar mampu melakukan edukasi pengelolaan keuangan kepada masyarakat

\section{METODE}

Metode pewlaksanaan dalam kegiatan pengabdian masyarakat ini dilakukan dalam bentuk pelatihan di dalam kelas dengan menggunakan metode brainstorming, ceramah, diskusi dan tanya jawab serta praktek pembukuan dengan menggunakan aplikasi pembukuan MYOB secara langsung dengan menggunakan computer. Pelatihan dibagi kedalam 2 sesi yaitu sesi pembekalan materi dan sesi praktek aplikasi pembukuan.

\section{PEMBAHASAN}

Pelaksanaan kegiatan Pelatihan Pengelolaan Keuangan UPK ini diawali dengan pembekalan materi . Materi Pelatihan Pengelolaan Keuangan meliputi, Managemen Keuangan, Dasardasar Akuntansi, Pengenalan aplikasi MYOB dan Praktek Pembukuan dengan menggunakan aplikasi MYOB.

1. Manajemen Keuangan

Manajemen Keuangan menurut Sutrisno (2012:3) adalah "semua aktivitas perusahaan yang berhubungan dengan usaha - usaha mendapatkan dana perusahaan dengan biaya yang murah serta usaha untuk menggunakan dan mengalokasikan dana tersebut secara efisien" sementara menurut Menurut Kamaludin (2011:1) manajemen keuangan adalah , " Upaya untuk mendapatkan dana dengan cara yang paling menguntungkan serta mengalokasikan dana secara efisien 
Vol. 1, No. 2, Jul 2018, hlm. $63-68$

ISSN 2614-7912 (cetak)

ISSN 2622-3813 (online)

Available online at http://jurnal.stmikroyal.ac.id/index.php/jurdimas

alam perusahaan sebagai sarana untuk mencapai sasaran bagi pemegang saham

\section{Dasar-Dasar Akuntansi}

Menurut Hans Kartikahadi, dkk. (2016:3) pengertian akuntansi adalah : "Akuntansi adalah suatu sistem informasi keuangan, yang bertujuan untuk menghasilkan dan melaporkan informasi yang relevan bagi berbagai pihak yang berkepentingan". Adapun definisi akuntansi menurut A.L. Haryono Jusuf (2011) adalah sebagai berikut: "Suatu proses pencatatan, penggolongan, peringkasan, pelaporan dan

penganalisaan data keuangan dari suatu organisasi"

Pada dasarnya pengertian akuntansi mengandung 3 (tiga) unsur pokok yaitu :

1. Merupakan proses pengukuran dan pengkomunikasian data keuangan.

2. Berhubungan dengan suatu satuan ekonomi tertentu .

3. Ditujukan bagi pihak-pihak yang berkepentingan sebagai bahan pertimbangan didalam pengambilan keputusan.

\section{Siklus Akuntansi}

Siklus Akuntansi bersifat akuntabel serta harus dapat dipertanggung jawabkan isinya, karena disusun dengan kaidah dan prinsip akuntansi. Berikut adalah gambar siklus akuntansi manual:

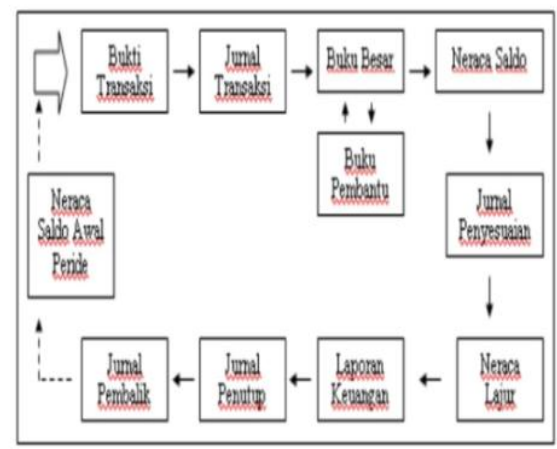

Gambar 1. Siklus Akuntansi Manual

\subsection{Siklus Akuntansi Komputerisasi}

Saat ini sudah banyak perusahaan yang merubah sistem akuntansi manual ke sistem akuntansi komputerisasi . Perubahan ini disebabkan karena beberapa kelebihan dari sistem komputerisasi seperti proses akuntansi tidak membutuhkan waktu yang lama serta dapat meminimaisir kesalahan. Adapun siklus akuntansi komputer yaitu:

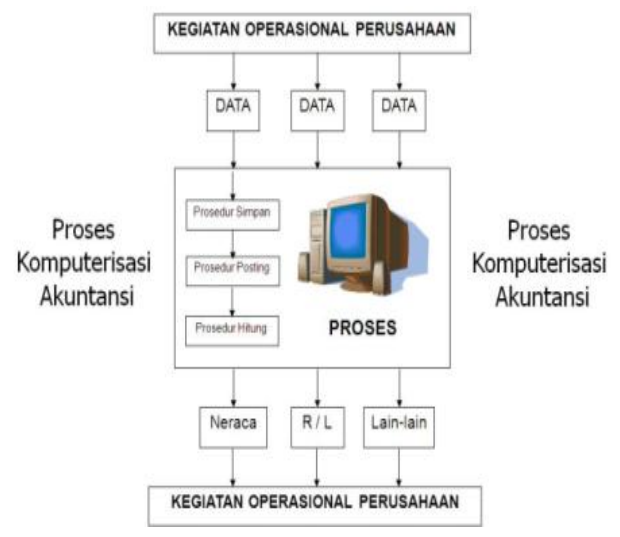

Gambar 2. Siklus Akuntansi

Komputerisasi

Menurut Mardi

(2011)

Karekteristik Sistem Akuntansi Komputer adalah sebagai berikut:

1. Modul buku besar menjadi sebagai data stronge.

2. Kebutuhan informasi dapat dilakukan langsung ke database sistem.

3. Informasi keuangan yang dapat dimunculkan segera serentak melalui media windows.

4. Pencatatan data akuntansi berupa buku besar dan buku pembantu di simpan di sistem database.

5. Perangkat keras dan perangkat lunak teknologi dominan digunakan.

6. Dapat dilakukan jejak audit berdasarkan bagan alir program dan bagan alir sistem yang tersedia.

7. Peranan tenaga manusia terbatas pada entry data.

8. Rawan terhadap serangan virus komputer. 
Vol. 1, No. 2, Jul 2018, hlm. $63-68$

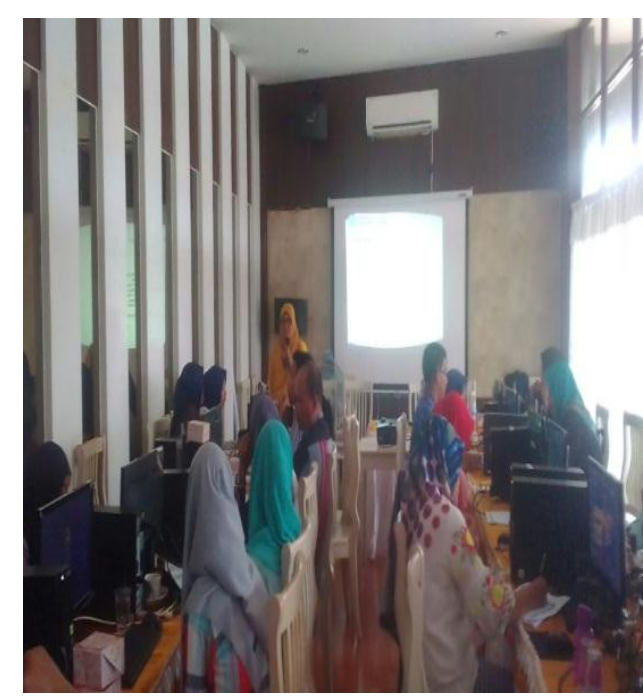

4 Pengenalan Program Myob

Siklus Akuntansi Program Myob

Menurut Zainuri (2007:53) Siklus

Komputer Akuntansi program Myob Accounting adalah sebagai berikut:

1. Tahap Persiapan

Perusahaan yang ingin mengolah data akuntansinya dengan kornputer program

Myob Accounting, harus mempersiapakan Seperangkat Komputer serta mempunyai software Myob

2. Tahap Installasi Program Myob Accounting

Installasinya adalah:
a. Masukkan Software Accounting ke CD ROM
b. Aktiftan Jendela Explore (Klik kanan Staft Menu, Explore)
c. AKifkan drive E:
d. Aktifkan Folder Myob Accounting atau Myob Accounung 2007
e. Double klik Icon Setup
f. KIik Next, tunggu pross
g. Klik Finish

3. Menjalankan Program $M y o b$ Acoounting (Zainuri,2007: 53)

a. Mengaktifkan Program Myob Accounting. b. Membut file data akuntansi baru dan menyimpan.

c. Merancang dan Modifikasi Rekening :

- Menindih Rekening atau akun,

- Memanipulasi nomor akun.

- Menghapusteksakun.

- Menonaktifkan akun.

- Menghapus akun.

- Membuat akun baru.

- Menentukan tipe akun.

- Menentukan level akun

a. Mengatur Setup Pajak

b. Mengatur Linked Acoount.

c. Membuat kartu pelanggan dan mencatat syarat pembayaran.

d. Membuat kartu pemasok dan mencatat syarat pembayaran.

e. Keluar dari Program Myob Accounting.

f. Membuka File Data Akuntansi.

g. Memasukkan nomor registrasi

h. Memberi password pada data akuntansi

i. Mencatat transaksi

j. MenyusunLaporan Keuangan

k. Penutupan Buku

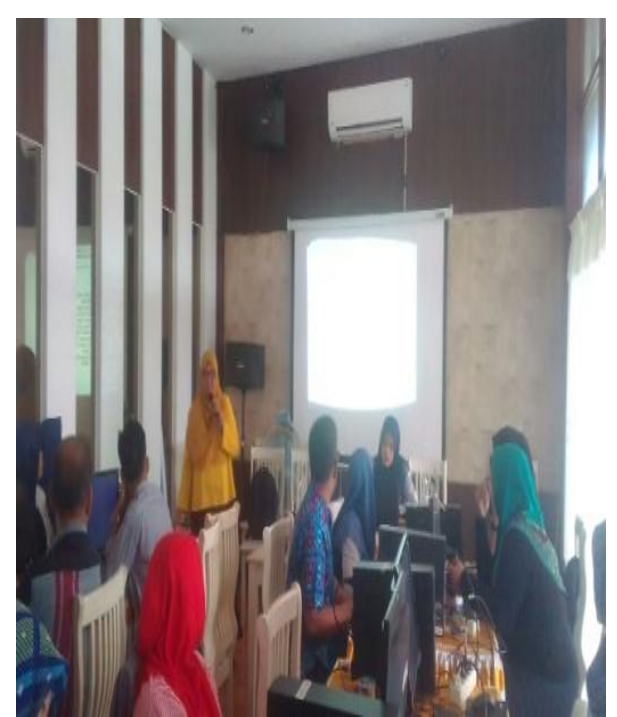

Gambar 4. Sesi Tanya Jawab

Modul-Modul Myob Accounting dan

Kegunaannya (Zainuri,2007:54)

1. ModulAccount 
Available online at http://jurnal.stmikroyal.ac.id/index.php/jurdimas

a. Digunakan untuk pemrograman dan modiftkas akun

b. Digunakan untuk pencatatan transaksi jurnal umum

c. Digunakan untuk melihat transaksi jurnal umum

2. Modul Banking

a. SpentMoney

b. Receive Money

3. Modul Purchase; untuk pencatata pembelian dan permasalahannya

4. Modul Time Billing; untuk mencatat transaksi-transaksi khusus

5. Modul Sales; untuk pencatatan penjualan dan permasalahannya

6. Modul Payroll; untuk pencatatan transaksi khusu penggajian

7. Modul Inventory; untuk pencatatan produk dan permasalahanya

8. Modul Card File; untuk membuat kartu piutang, kartu hutang dan data karyawan

\section{SIMPULAN}

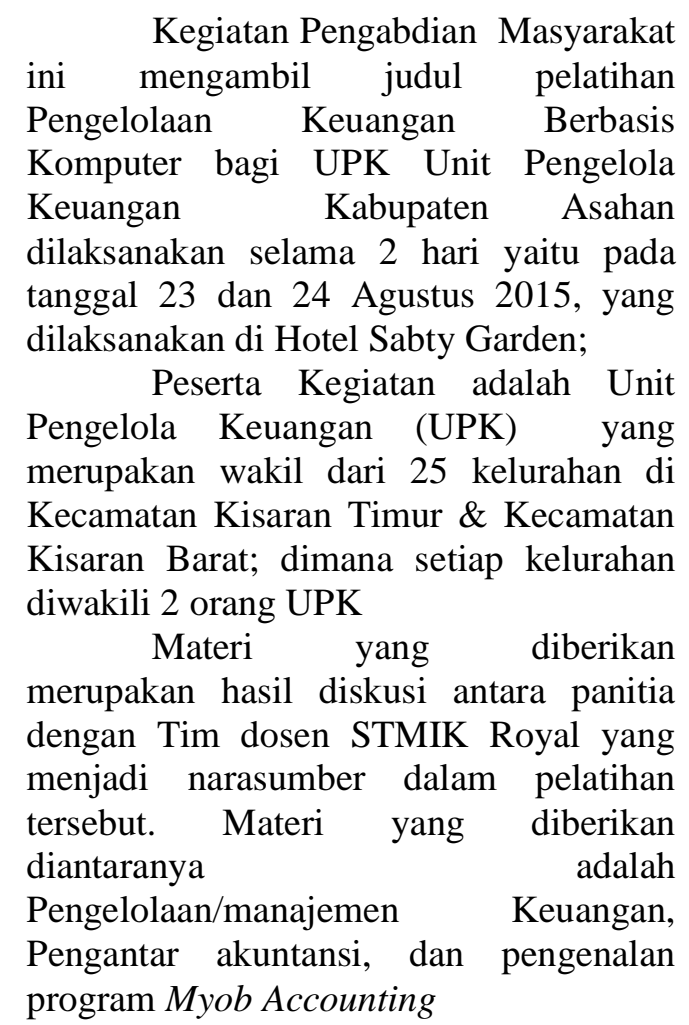

Hasil dari kegiatan PkM ini adalah pelatihan berjalan dengan baik, lancar dan mendapat respon yang sangat positif dari peserta, hal ini terlihat dari banyaknya pertanyaan-pertanyaan yang diajukan peserta kepada narasumber

\section{UCAPAN TERIMA KASIH}

Kegiatan pengabdian kepada masyarakat ini tentunya, tak terlepas dari bantuan berbagai pihak, untuk itu ucapan terima kasih kami sampaikan kepada:

1. Bapak Anda Putra Lubis, SE., MMA, Ketua Yayasan Royal Teladan Asahan, sebagai penyandang dana,

2. Bapak Asisten Koordinator Kota Program Kota Tanpa Kumuh Kabupaten Asahan beserta seluruh fasilitator dan senior fasilitator

3. Bapak/ibu Koordinator BKM Kecamatan Kisaran Barat \& Timur

4. Tim pengabdian kepada masyarakat yang telah bekerjasama dengan baik, sehingga kegiatan dapat berjalan lancar dan sukses.

\section{DAFTAR PUSTAKA}

AL. Haryono Jusup.2011. Dasar - Dasar Akuntansi JILID I EDISI KE-7. STIE YKPN.

Hans Kartikahadi., dkk. 2016. Akuntansi Keuangan Berdasarkan SAK Berbasis IFRS Buku 1. Jakarta : Salemba Empat.

Sutrisno. 2012. Manajemen Keuangan Teori, Konsep dan Aplikasi. Yogyakarta: EKONISIA

Kamaludin.2011. Manajemen Keuangan Bandung:Mandar Maju

Kementrian Pekerjaan Umum Direktorat Jenderal Cipta Karya ( ) Petunjuk Teknis Pembukuan UPK

Mardi. 2011. Sistem Informasi Akuntansi. Bogor: Penerbit Ghalia Indonesia 
Jurdimas (Jurnal Pengabdian Kepada Masyarakat) Royal

Vol. 1, No. 2, Jul 2018, hlm. $63-68$

ISSN 2614-7912 (cetak)

Available online at http://jurnal.stmikroyal.ac.id/index.php/jurdimas

Mochamad Zainuri. 2007. Mengapa Myob Accounting Banyak Menjadi Pilihan Perusahaan Sebagai Sistem
Pengolahan Data Akuntansinya Journal AMIK JTC Semarang ol 3 No.2 